\title{
Conflict and its governance in horizontal cooperations of logistics service providers
}

\author{
Carl Marcus Wallenburg \\ Lehrstuhl für BWL, insbes. Logistik und Dienstleistungsmanagement, \\ WHU - Otto Beisheim School of Management, \\ The Kuehne-Foundation Chair of Logistics and Services Management, \\ Vallendar, Germany, and \\ Jan Simon Raue \\ Kuehne-Foundation Chair of International Logistics Networks, \\ Technische Universität Berlin, Berlin, Germany
}

\begin{abstract}
Purpose - Horizontal cooperations of logistics service providers (LSPs) have become important for LSPs within the last decades. Owing to the high complexity of these cooperations as observed by Schmoltzi and Wallenburg, the potential for conflict is inherent. This research, therefore, aims to investigate how nature (dysfunctional vs functional) and extent of conflict impact the outcome of these cooperations. Further, the roles of formal and relational governance mechanisms in influencing conflict are analyzed.

Design/methodology/approach - The research is empirical in nature and employs a theory-driven, confirmatory approach. It utilizes large-scale survey data of German LSPs, which are analyzed using multivariate statistical methods.

Findings - The research shows that governance mechanisms impact the extent and functionality of conflict: relational governance lowers the extent of conflict and leads to higher functionality of conflicts, while formal governance increases the extent of conflict. Moreover, it is shown that conflicts decrease the overall cooperation performance, whereas - when functional in nature - they have a positive impact on the innovativeness of cooperations.

Research limitations/implications - The impact of governance on conflicts and of conflicts on outcome may differ depending on the cultural and country-specific setting.

Practical implications - The results allow mangers of LSP cooperations to adapt their set of applied governance mechanisms and conflict resolution approaches with regard to the improvement of cooperation performance and cooperation innovation.

Originality/value - This is the first study that analyzes conflict and conflict resolution in horizontal LSP cooperations and shows their interrelation with both governance and performance.

Keywords Conflict resolution, Corporate governance, Servicing, Performance management, Innovation Paper type Research paper

\section{Introduction}

As the complexity and dynamics of supply chains have increased, so have the challenges for logistics service providers (LSPs) as key players in the management and execution of logistics. One viable way for LSPs to react to these challenges is to strengthen

The authors want to thank Christina Schmoltzi, PhD-Candidate at WHU - Otto Beisheim School of Management, for support in the data collection and especially for her valuable contributions in discussing the governance and control of horizontal LSP cooperations.
\end{abstract}

Conflict and its governance 
IJPDLM

41,4

386 interaction - either vertically with customers and suppliers or horizontally with other LSPs. In the recent past-an increasing number of LSPs has decided to utilize the latter option and to establish horizontal logistics cooperations (Carbone and Stone, 2005; Oum et al., 2000). These partnerships enable LSPs to enhance their competitiveness and to enforce their market penetration capabilities, not only by providing access to new markets or by increasing profitability, but also by extending service portfolios and improving service quality (Cruijssen et al., 2007a, b; Carbone and Stone, 2005).

Recently, nearly 60 percent of German LSPs participate in one or more horizontal cooperations and, for the future, only 3 percent of LSPs want to reduce their overall engagement in horizontal cooperations, while 69 percent plan to stay at the current level, and 28 percent intend to further increase their usage (Schmoltzi and Wallenburg, 2009).

While vertical cooperations between LSPs and shippers have already been covered by an abundant body of literature investigating, for instance, the typology of partners and their relationships (Knemeyer et al., 2003; Lambert et al., 1996; Stefansson, 2006), success factors of these vertical logistics cooperations (Lambert et al., 1999; Moore, 1998; Tate, 1996), and attributes of partnership performance (Deepen et al., 2008; Gibson et al., 2002; Stank et al., 2003), research on horizontal cooperations between LSPs is still at an early stage. Despite the growing popularity of these inter-firm exchanges, existing studies have been mainly limited to a number of case studies, focusing on specific logistics business modes (e.g. road: Lemoine and Dagnæs, 2003; Ludvigsen, 2000; rail: Ohnell and Woxenius, 2003; Nijkamp, 1995; sea: Slack et al., 2002; Midoro and Pitto, 2000; air: Oum et al., 2004; Fan et al., 2001; Glisson and Cunningham, 1996). As notable exceptions, Cruijssen and his colleagues provide an extensive literature review (Cruijssen et al., 2007a), first large-scale empirical results on opportunities and impediments of horizontal LSP cooperations (Cruijssen et al., 2007b), and conceptual deliberations on a framework for managing these cooperations (Verstrepen et al., 2009), while Schmoltzi and Wallenburg (2009) provide empirical insights into the motives, structures, and performance of horizontal LSP cooperations.

Owing to the high complexity of these cooperations as observed by Schmoltzi and Wallenburg (2009), the potential for conflict is inherent. While conflict per definition merely refers to disagreement between two or more parties, it is - due to the friction involved with conflict - most often viewed negatively and as a state that has to be overcome (Andrade et al., 2008). This is mostly mirrored by managers who view conflict as something to be avoided or immediately resolved (Jehn, 1997; Andrade et al., 2008) and that should be counteracted through rules and control mechanisms (Verstrepen et al., 2009). This view, however, neglects the potential positive effects conflicts may have in relationships. They facilitate the exchange of ideas, may foster the integration of different views and perspectives, and through creative tension may fuel growth and innovation (Menon et al., 1996; Andrade et al., 2008). While the performance outcome of conflict has been ambiguous and subject to much discussion, it is consensus that the extent and nature of conflict can be influenced by the context of the relationship (Barclay, 1991) and by both formal and relational governance mechanisms.

In spite of the abundant research on conflict conducted in the past, the extant literature does not provide specific insights into this domain with respect to horizontal LSP cooperations. Conflicts in horizontal cooperations can be expected to differ from those in other inter-organizational relationships. Compared to vertical cooperations higher potential for opportunism and dysfunctional conflicts emerges as partnering firms 
are competing for the same customers (Tidström, 2009). Furthermore, interdependencies between the partnering firms can be expected to be lower, as partners do not rely on the output of partners as input for their own operations (Rindfleisch, 2000). Therefore, cooperating firms tend to escalate problems more quickly. Also, the sharing of profits and risks of common operations is a source of conflict inherent in horizontal cooperations rather than in vertical ones, as competitors have precise insights into the services performed together. Additionally, unequally distributed power within cooperations is a natural source of conflict as less powerful partners are likely to feel discriminated. Altogether, this emphasizes that a conflict-oriented governance of horizontal cooperations may foster its success.

This research, therefore, aims to reduce the existing research gap by providing insights into the effects different governance mechanisms (formal and relational) have on the emergence and nature of conflicts in horizontal LSP relationships, and subsequently on the outcome of these cooperations. For this, we employ a quantitative empirical approach to describe and analyze governance, conflicts, outcomes as well as their interrelations based on a sample of 212 LSPs that are engaged in horizontal cooperations. The remainder of the paper is organized as follows: we first provide a conceptual framework and hypotheses, which then are tested using structural equation modeling. The corresponding results are then discussed and reflected with respect to the extant literature before providing implications for practice and future research.

\section{Conceptual framework}

2.1 Outcome of conflict

Conflict describes a situation where two or more parties are in disagreement. As such, conflict carries negative connotations due to several reasons. First, resolving a conflict (i.e. create a state of agreement) is resource consuming and, therefore, imposes costs on the conflicting parties. Further, the corresponding process may cause distraction to the management of the cooperation and divert attention from matters of greater importance or urgency. It also affects information processing negatively (De Dreu and Weingart's, 2003) and may deteriorate trust and commitment (Verstrepen et al., 2009) as parties may feel increased uncertainty regarding the other party and may fear opportunism. Second, if a conflict is not resolved it may affect outcomes negatively as disagreement about a certain subject may translate into disunity of effort and foregoing benefits that would be obtainable if such effort had been reached. Overall, these notions are reflected in two research streams that view conflict:

(1) as organizational dysfunction; or

(2) as a group impediment.

Consequently, Verstrepen et al. (2009) advise LSPs to reduce conflict in horizontal cooperations.

Contrasting this, other streams of literature shed a more positive light on conflict and promote it to improve the processes of decision making (Janis, 1972; Schweiger et al., 1989; Menon et al., 1996). Opposing ideas may generate a creative tension, which fosters learning and development through the exchange of different perspectives. Even when not bridged, disagreements can be utilized to gain a better understanding of the different goals and perspective of each party, which subsequently can be accounted for in the process of decision making. Some researchers (Andrade et al., 2008) even go one step
Conflict and its governance

387 
IJPDLM

41,4

388 further and proclaim that conflict is not only inherent in any complex system, but is necessary as fundament for growth and development of such system and in this way fuel innovation in horizontal cooperations.

To cater for these different views, we look at the occurrence of conflicts in twofold ways by referring to extent and to functionality of conflict. The extent of conflict reflects the view of Jehn (1994) and Amason (1996) and focuses on the quantity of conflict - the extent to which disagreements and differences about ideas and decisions occur within the respective cooperation. The functionality of conflict reflects the quality of conflict inherent in cooperations between LSPs by differentiating between functional and dysfunctional conflicts. Functional conflict refers to a constructive, substantive, and task-oriented form of conflict(Menon et al., 1996), which is often found in successful and innovative organizations (Eisenhardt and Bourgeois, 1988; Pascale, 1990). On the other side, dysfunctional conflict refers to destructive, emotional, and personal disagreement. By creating obstacles, such as distortion and withholding of information, involved managers lower the quality of decision-making processes within their organizations (Menon et al., 1996).

Based on this differentiation, it can be concluded that conflict is both good and bad for the outcome of horizontal cooperations. With respect to extent of conflict, we follow the notion of the first research stream and posit that conflict always entails at least certain elements of friction that may disturb interaction and collaboration, affects information processing negatively (De Dreu and Weingart, 2003) and may deteriorate trust and commitment (Verstrepen et al., 2009). In this sense, less conflict is better for the cooperation outcome than more conflict and, thus, extent of conflict will have a negative effect. However, based on the reasoning of Andrade et al. (2008), it can also be concluded that functional conflict is better for cooperations than dysfunctional conflict and, thus, quality of conflict to have a positive outcome effect.

Within the outcome dimension, two relevant aspects can be differentiated that serve as a yardstick to assess whether quantity and quality of conflict are good or bad for horizontal LSP cooperations. The first outcome variable is the performance of the cooperation referring to the question whether the cooperation fulfills its core objectives (Saxton, 1997; Kale et al., 2002). The second outcome variable is cooperation-based innovation. In this respect, Andrade et al. (2008) emphasize the potential conflicts offer to gain new perspectives and insights and create innovations. Such innovations have been shown to be essential for service providers to improve their competitive positioning (Calantone, 2002; Dilk et al., 2008; Grawe et al., 2009; Kandampully, 2002). Here, cooperation-based innovation (Nielson and Nielsen, 2009) offers two possible benefits as it fosters the further positive development of the specific cooperation in which the innovation originates, but can also be utilized outside when transferred back to the single company and used for that company's own business. Consequently, we hypothesize:

H1. Extent of conflict within a horizontal LSP cooperation affects performance of the cooperation negatively.

H2. Extent of conflict within a horizontal LSP cooperation affects innovation of the cooperation negatively.

H3. Functionality of conflict within a horizontal LSP cooperation affects performance of the cooperation positively. 
H4. Functionality of conflict within a horizontal LSP cooperation affects cooperation-based innovation positively.

\section{Conflict and its} governance

\subsection{Influencing conflict through governance}

Governance is a fundamental aspect that influences how companies engage and interact within relationships. As Verstrepen et al. (2009) emphasize, also conflict in horizontal LSP cooperations can be influenced by the rules and control mechanisms in place. Drawing on the extant literature, formal and social control can be identified as key elements in this respect.

Formal control mechanisms emphasize the usage of formalized and mutually binding agreements. They rely on written documents, like standard operating procedures, set forth rules, responsibilities and procedures, and specify outcomes and behavior to be expected (Das and Teng, 1998; Li et al., 2010; Ouchi, 1979). By formalizing both interaction and roles, formalization helps to align partners' interests and to clarify interdepartmental responsibilities (Zaltman et al., 1973) and reduces role conflict, role stress, and role ambiguity (Jaworski and MacInnis, 1989; Menon et al., 1996). This not only helps to reduce the extent of conflict as underscored by Barclay (1991), but should also foster functionality of conflict as disagreements will be channeled through formalization and will, thus, be relatively more task oriented.

Many scholars already acknowledge that cooperation management is not solely governed by formal but also by self-enforcing provisions referred to as social control mechanisms, which are manifested in personal interactions. Following the social exchange perspective, cooperative exchanges are embedded within a system of social interactions (Poppo and Zenger, 2002; Granovetter, 1985) that help to build relational capital. Such relational capital involves an atmosphere of forbearance, respect and balanced reciprocity. Further, it creates a mutual confidence that no party will exploit others' vulnerabilities even if there is such opportunity (Kale et al., 2000). In this context, and contrasting formal control mechanisms, where obligations and outcomes are predefined, social control mechanisms rely on unspecified obligations partners cannot bargain about (Blau, 1964). Relational capital increases understanding of each other's positions, which reduces the likelihood of disagreement and will facilitate keeping conflicts productive and task-oriented when they arise. Additionally, the general reciprocity that is induced by relational capital will make it easier to bridge opposing views and disagreements, as decisions are not seen as single episodes that have to yield equal or at least equitable outcomes for all parties, but rather as sequences in an enduring relationship where gains only need to be equitable in the long run.

Based on the above reasoning, we conclude that the two described aspects of governance - formal and social control - both reduce quantity of conflict and increase quality of conflict:

H5. Formalization of horizontal LSP cooperations reduces the extent of conflict of these cooperations.

H6. Formalization of horizontal LSP cooperations increases the functionality of conflict of these cooperations.

H7. Relational capital of horizontal LSP cooperations reduces the extent of conflict of these cooperations. 
IJPDLM

41,4

\section{0}

\section{Research methodology}

\subsection{Sample}

Before collection of data, pretest interviews were carried out with five CEOs of LSPs and six researchers. These interviews served to validate the relevance of the governance and conflict categories, to optimize the survey instrument for its comprehensibility, and to assure content and face validity.

The sampling was performed by using the Hoppenstedt database, which contains corporate information on German firms with an annual turnover of more than $€ 1$ million. Potential respondents were selected based on 24 logistics-specific NACE codes (i.e. "Nomenclature Statistique des Activités Économiques dans la Communauté Européenne") and corresponding industry descriptions.

Drawing on Kumar et al. (1993), we applied a key informant approach. This implied addressing the most knowledgeable person in terms of firm-specific cooperation experiences. Thus, we addressed CEOs or alternatively managers at the executive level. Consistent with the guidelines set forth by Griffis $e$ t al. (2003), a web-based survey method was employed, and sample members were contacted in October 2009 via e-mail asking them to complete the online questionnaire. A total of 3,661 of the e-mail contacts proved to be valid. Following the recommendations of Larson and Poist (2004), incentives and friendly reminder e-mails were used to increase the response rate.

A total of 389 respondents answered the survey, a response rate of 10.6 percent. An examination of the demographics suggests that the complete sample is well balanced regarding company size and is representative for small, medium, and large LSPs. Of the 389 responses, 229 could potentially be used in this research as only they stem from LSPs that engage in horizontal cooperations with other LSPs, while the other 160 where from LSPs that did not engage in such cooperations. The questionnaires were then checked for incomplete data, leaving 212 usable datasets. As suggested by Kumar et al. (1993), respondent competency was assessed on the basis of personal information provided by the participants. About 65 per cent of the respondents make up the CEO, 15 per cent are other members of the executive board, and further 13 per cent fill another leading management position. In addition, the informants have an average professional experience within their company of more than 13 years, indicating their familiarity with firm-specific strategies and processes. Non-response bias was first assessed by comparing early and late respondents, yielding no significant differences between these two groups. Additionally, available demographic data of responding and non-responding companies from the original databases were compared, and, again, no significant differences were found. Both tests indicate that non-response bias is of non-significant relevance in this study.

\subsection{Measurement model assessment}

The measurement of all constructs relied upon multi-item seven-point scales, which were derived from logistics and strategic management literature and are displayed in the Appendix.

Cooperation performance was measured based on the alliance performance scales of Saxton (1997) and Kale et al. (2002). From the latter, two items were excluded as one item referred to ability to learn from its partners and a second to the quality of relationship. 
These two aspects were already captured in two other constructs (cooperation-based innovation and relational capital). Cooperation-based innovation was measured with the scale of Nielson and Nielsen (2009).

The extent of conflict was captured by the cognitive conflict scale of Amason (1996), who builds upon Jehn (1994). To measure functionality of conflict, we used a new developed semantic differential scale with three items that capture to what degree conflicts were task oriented (opposed to personal and emotional), facilitate collaboration (opposed to hamper collaboration), and are productive (opposed to destructive).

Formal control was measured using the formalization scale of Murray and Kotabe (2005) from which one item was eliminated in the scale refinement process. Relational capital was measured with the scale of Kale et al. (2000).

For assessment of scale reliability and validity SPSS 18.0 and Amos 18.0 were used. As displayed in the Appendix, Cronbach's alpha values were well above the suggested 0.7 (Nunnally, 1978) in all instances. Additionally, the results of the confirmatory factor analysis showed good model fit: $\chi^{2} / \mathrm{df}=1.322$, CFI $=0.984$, TLI $=0.981$, and RMSEA $=0.039$. All factor loadings are significant at the $p<0.001$ level, supporting convergent validity for the constructs (Bagozzi et al., 1991; Anderson et al., 1987). Discriminant validity was examined using the Fornell and Larcker (1981) criterion. For all item scales the squared correlation did not exceed the average variance extracted, indicating discriminant validity.

\subsection{Hypotheses testing}

The conceptual model was assessed using structural equation modeling. Again the fit indices suggest sound model fit $\left(\chi^{2} / \mathrm{df}=2.036, \mathrm{CFI}=0.948, \mathrm{TLI}=0.938\right.$, and RMSEA $=0.070$ ), thus allowing for an examination of the individual hypotheses (Byrne, 1994).

$H 1$ and $H 2$ examine the effect of extent of conflict within horizontal cooperations of LSPs with respect to cooperation performance and cooperation innovation, presuming a negative influence on both outcome dimensions. As shown in Figure 1, the impact on cooperation performance is negative and highly significant $(-0.410, p<0.001)$, whereas the impact on cooperation-based innovation is slightly positive, but non-significant $(+0.066, p>0.35)$. Therefore, $H 1$ finds support, whereas $H 2$ is to be rejected.

Further effects on performance and innovation are examined by $H 3$ and $H 4$, presuming positive impacts of functionality of conflict on the two aforementioned outcome constructs. Indeed, both relationships show to be positive and significant - the effect exerted by the functionality of conflict on cooperation performance results

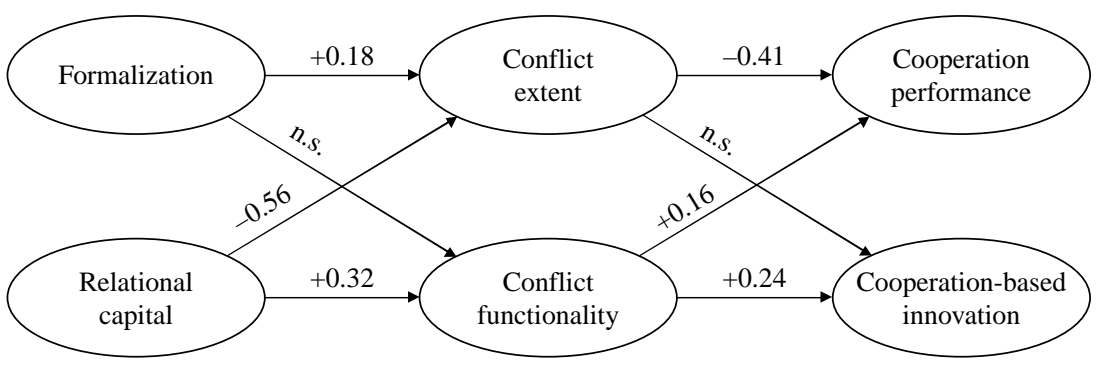

Note: Displayed path coefficients are standardized
Conflict and its governance

391 
IJPDLM

41,4

392 in a path coefficient of $+0.162(p<0.02)$. Furthermore, the functionality of conflict has a significantly positive impact $(+0.239, p<0.005)$ on innovation in cooperations between LSPs, thus providing evident support for $H 3$ and $H 4$.

If effects of both quantity and nature of conflict are combined, 21.9 percent of variance in cooperation performance and 5.6 percent of variance in cooperation innovation are explained.

$H 5$ and $H 6$ posit a negative effect of formalization on extent of conflict and a positive effect on functionlity of conflict. Surprisingly, model results indicate a significant positive effect of formalization on the extent of conflict with a path coefficient of +0.177 $(p<0.01)$ and no significant relationship between formalization and functionality of conflict $(-0.026, p>0.70)$. This leads to the rejection of both $H 5$ and $H 6$.

$H 7$ and $H 8$ posit relational capital to reduce the extent of conflict and to have a positive influence on the functionality of conflict. Both hypotheses find support as the effect on extent of conflict is $-0.556(p<0.001)$ and on functionality of conflict $+0.317(p<0.001)$.

When the effects of formalization and relational capital are combined, they produce $R^{2}$ of 34.0 percent for extent of conflict and 10.1 percent for functionality of conflict.

\section{Discussion}

4.1 Interpreting the outcome of conflict

The tested model shows that conflict has a different impact on cooperation performance than on cooperation-based innovation. With respect to innovation, the gained results require careful interpretation. While extent of conflict has no significant influence on innovation, functionality of conflict has. But does this mean that it really does not matter how much conflict is present, but only which type? This is not the case and the results, here, may - at first sight - be misleading. As extent and functionality of conflict show to be completely uncorrelated $(p>0.95)$ in their occurrence, the non-significant effect of conflict extent has to be interpreted that at average levels of conflict functionality it does not matter how much conflict is present (effect of conflict extent is non-significant in the full sample). Yet, this results from the fact that more functional conflict is good, while more dysfunctional conflict is bad for innovation as shown in Figure 2. Such can be shown by conducting additional moderation analysis and assessing the innovation and performance effect of the interaction of extent and of functionality of conflict. When splitting the sample at the median, conflict extent in the low conflict functionality group (which has a mean functionality score of 3.27 on scale from 1 to 7 ) has an effect on cooperation-based innovation of -0.047 (n.s.). In contrast, in the high conflict functionality group (mean score of 5.74) the effects of conflict extent are $+0.224(p<0.04)$ for innovation.

In this sense, the results underscore the view of Andrade et al. (2008) that conflict is a source to achieve creative tension and to fuel growth and innovation within horizontal LSP cooperations that comprise complex systems. This positive effect can be traced back to the clash of opposing views and surfacing of new ideas that arises from different perspectives. This, however, only holds true as long as conflict is functional. The innovation potential decreases as dysfunctional elements begin to surface, and conflict eventually turns negative, which includes obstacles, such as distortion and withholding of information (Menon et al., 1996).

A certain setback to role of conflict in the process of learning and innovation can be seen in the low variance explained of 5.6 percent. This, however, should be seen in the light that innovativeness is generally low at LSPs (Wagner, 2008; Wallenburg, 2009) that innovation 


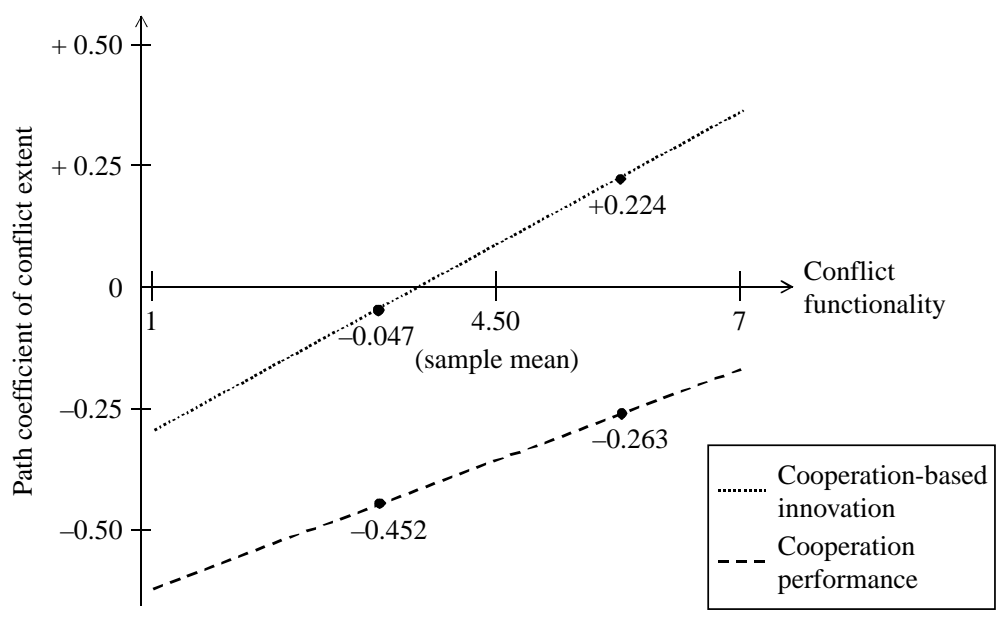

\section{Conflict and its governance}

Note: Displayed path coefficients are standardized

creation at LSPs still is not well understood, and that conflicts within LSP cooperations are only one of many elements that impact this facet of the cooperation.

In contrast, a very different picture can be viewed with respect to overall performance. The hypotheses test shows that extent of conflict has a strong negative effect on performance $(-0.410)$, which can only partially be offset by the positive effect of conflict functionality $(+0.162)$. This finding is affirmed by the moderation analysis, which illustrates that for cooperation performance not only more dysfunctional conflict is bad, but even more functional conflict as the path coefficient of conflict extent is neagative for all levels of conflict functionality. This is consistent with the "traditional" view on conflict, which is seen as an organizational dysfunction or as a group impediment (Andrade et al., 2008). An explanation for this can be seen in the fact that horizontal LSP cooperations apparently are predominantly based on smooth operations that do not require creative tension and constant innovation. In such a setting turbulence that stems from disagreements and conflicts will create friction that consumes resources, diverts management attention from matters of greater importance, and affects information processing negatively (De Dreu and Weingart's, 2003). Further, unresolved conflicts translates into disunity of effort, which leads to foregoing benefits that would be obtainable if such effort had been reached. It would also explain why conflict plays such a substantial role for performance and is able to explain 21.9 percent of variance in this outcome variable.

\subsection{Interpreting how to govern for or against conflict}

The results show that governance addresses both relevant outcome levers viewed in this research: the extent and the functionality of conflict. When reflecting upon which governance to emphasize, it has to be recapitulated that in all instances where conflict is present it is better for this conflict to be functional rather than dysfunctional. However, more conflict can only be good for a horizontal LSP cooperation when this conflict is actually functional - and even then only with respect to learning and innovation and not for overall performance. This means, while functional conflict is good for innovation at the same time it is detrimental for performance. 
IJPDLM

41,4

394
Overall, this implies that governance should be directed most often at avoiding conflict and only at fostering functional conflict, if the cooperation is long-term oriented and focuses on innovation potential more than on immediate performance outcomes, or in cases where conflict as force for improvement can be isolated in a way that it only impacts innovation and does not show its detrimental performance effect. This may be realized by having special personnel or teams that focus on learning and innovation only and are detached from day-to-day operational business.

In this context, relational capital shows the biggest potential as it both is able to substantially reduce extent of conflict and foster functionality of conflict. This is consistent with Kale et al. (2000), who show that relational capital provides a solid fundament for alliances and fosters learning as well as it helps to protect specific investments and proprietary elements. Overall, this emphasizes how important common norms and shared values as well as building trust over time are for such relationships. In a setting where potential competitors may operate in similar markets, with similar services, based on similar competencies, or may address similar customer groups, relational capital also helps to bridge this competitive tension.

In contrast, formalization has only a small, albeit detrimental effect as it increases extent of conflict and even slightly, yet non-significantly, makes conflicts more dysfunctional. Rather than clarifying roles and setting guidelines for interaction which target the potential source of conflict, formalization and the corset it provides, is by itself a source of conflict. A potential explanation of this can been seen in the fact that in complex and dynamic environments, as omnipresent today, not all contingencies can be foreseen and be catered for ex ante. Yet, when deviations from expectations occur, formalization is likely to involve some parties of the cooperation that will want to stick to rules set out - at least as much as possible - while others may see the necessity to deflect from the guidelines. Especially, in business environments as Germany, where rules and regulations play an important role and are something that should be adhered to (Hofstede, 2001), the described opposing views will almost certainly cause conflicts, which are likely to leave the pure task-oriented level and become personal, emotional, and ultimately dysfunctional.

\subsection{Managerial implications}

Relating to the introduction, where it was described that horizontal LSP cooperations due to their complex nature offer high potential for conflict, the descriptive results gained in this result show that extent of conflict is not high in these cooperations. The conflicts that arise are very mixed in nature and include the full spectrum from dysfunctional to functional conflict. Actually, additional analyses show that complexity in terms of geographical reach does not significantly affect the quantity and quality of conflict, while the number of involved companies has no effect on quality of cooperation, but is strongly associated with the quantity of conflict, i.e. the more companies the cooperation encompasses, the greater the extent of conflict will be $(p<0.01)$.

With respect to management of LSP cooperations, the results also highlight the fact that to improve the performance of cooperations, conflict should be avoided in general. This does not mean that in each and every instance conflict is negative for operating a horizontal cooperation, but overall its detrimental nature should be noted. With respect to innovation, conflict has a different effect. Conflict through the exchange of opposing views should be fostered as long as it stays functional to utilize its creative tension. 
The effects of formalization and relational capital clearly point out that higher levels of formalization by no means are useful to reduce conflict and to make it more functional by providing clear guidelines. Instead, more formalization actually is detrimental in terms of conflict and should only be pursued as a strategy for governance, if it has other positive effects for the relationship that lie outside the scope of this research. A viable option to improve cooperation outcomes - both performance and innovation - is to facilitate the creation of relational capital as it not only reduces quality of conflict but also improves its quality.

\subsection{Limitations and future research}

The focus on Germany and on LSPs for data collection have to be regarded as the biggest limitation of this study as effects of governance may depend on the specific culture of the managers involved in these relationships. From a viewpoint of generalizablity, we believe that the effects of governance might be somewhat country- and culture-specific, but rather independent to the specific services underlying the cooperation. This would mean that results relating to antecedents of conflict also apply to financial services and IT-services, to only name two. Contrasting this, outcomes of conflict can be expected to be more independent from the country- and culture-setting, but may show certain variance across different types of services. Assessing this more in depth would be valuable to even better understand the emergence and role of conflict across different country- and service-settings.

\section{References}

Amason, A.C. (1996), "Distinguishing the effects of functional and dysfunctional conflict on strategic decision making: resolving a paradox for top management teams", Academv of Management Journal, Vol. 39 No. 1, pp. 123-48.

Anderson, J.C., Gerbing, D.W. and Hunter, J.E. (1987), "On the assessment of unidimensional measurement: internal and external consistency, and overall consistency criteria", Journal of Marketing Research, Vol. 3 No. 14, pp. 396-402.

Andrade, L., Plowman, D.A. and Duchon, D. (2008), "Getting past conflict resolution: a complexity view of conflict”, Emergence: Complexity \& Organization (E:CO), Vol. 10 No. 1, pp. 23-38.

Bagozzi, R.P., Yi, Y. and Lynn, W.P. (1991), "Assessing construct validity in organizational research", Administrative Science Quarterlv, Vol. 36 No. 3, pp. 421-58.

Barclay, D. (1991), "Interdepartmental conflict in organizational buying: the impact of the organizational context”, Lournal of Marketing Research, Vol. 2, May, pp. 145-59.

Blau, P.M. (1964), Exchange and Power in Social Life, Wiley, New York, NY.

Byrne, B.M. (1994), Structural Equation Modeling with EQS and EQS/Windows, Sage, Thousand Oaks, CA.

Calantone, R. (2002), "Learning orientation, firm innovation capability, and firm performance", Industrial Marketing Management, Vol. 31, pp. 515-24.

Carbone, V. and Stone, M.A. (2005), "Growth and relational strategies used by the European logistics service providers: rationale and outcomes", Transportation Research Part E, Vol. 41 No. 6, pp. 495-510.

Cruijssen, F., Cools, M. and Dullaert, W. (2007a), "Horizontal cooperation in logistics: opportunities and impediments", Transportation Research Part E, Vol. 43 No. 2, pp. 129-42.

Cruijssen, F., Dullaert, W. and Fleuren, H. (2007b), "Horizontal cooperation in transport and logistics: a literature review”, Transportation Journal, Vol. 46 No. 3, pp. 22-39.

\section{Conflict and its} governance

395 


\section{IJPDLM}

41,4

396
Das, T.K. and Teng, B.-S. (1998), "Between trust and control: developing confidence in partner cooperation in alliances", Academv of Management Review, Vol. 23 No. 3, pp. 491-512.

De Dreu, C.K.W. and Weingart, L.R. (2003), "Task versus relationship conflict, team performance, and team member satisfaction: a meta-analysis", Lournal of Aphlied Psychology, Vol. 88 No. 4, pp. 741-9.

Deepen, J.M., Goldsby, T.J., Knemeyer, A.M. and Wallenburg, C.M. (2008), "Beyond expectations: an examination of logistics outsourcing goal achievement and goal exceedance", Lournal of Business Logistics, Vol. 29 No. 2, pp. 75-105.

Dilk, C., Gleich, R., Wald, A. and Motwani, J. (2008), "State and development of innovation networks: evidence from the European vehicle sector", Management Decision, Vol. 46, pp. 691-701.

Eisenhardt, K. and Bourgeois, L.J. (1988), "Politics of strategic decision making in high-velocity environments: towards a mid-range theory", Academv of Management Iournal, Vol. 31 No. 4, pp. 737-70.

Fan, T., Vigeant-Langlois, L., Geissler, C., Bosler, B. and Wilmking, J. (2001), "Evolution of global airline strategic alliance and consolidation in the twenty-first century", Lournal of Air Transport Management, Vol. 7 No. 6, pp. 349-60.

Fornell, C. and Larcker, D.F. (1981), "Evaluating structural equation models with unobservable variables and measurement error", Journal of Marketing Research, Vol. 18 No. 1, pp. 39-50.

Gibson, B.J., Rutner, S.M. and Keller, S.B. (2002), "Shipper-carrier partnership issues, rankings, and satisfaction", International Iournal of Phvsical Distribution \& Logistics Management, Vol. 32 No. 8, pp. 669-81.

Glisson, L.M. and Cunningham, W. (1996), "Airline industry strategic alliances: marketing and policy implications", International Iournal of Phvsical Distribution \& Logistics Management, Vol. 26 No. 3, pp. 26-34.

Granovetter, M. (1985), "Economic action and social structure: the problem of embeddedness", The American Journal of Sociology, Vol. 91 No. 3, pp. 481-510.

Grawe, S.J., Chen, H. and Daugherty, P.J. (2009), "The relationship between strategic orientation, service innovation, and performance", International Iournal of Phvsical Distribution \& Logistics Management, Vol. 39, pp. 282-300.

Griffis, S.E., Goldsby, T.J. and Cooper, M. (2003), "Web-based and mail surveys: a comparison of response, data and cost”, Lournal of Business Logistics, Vol. 24 No. 2, pp. 237-58.

Hofstede, G. (2001), Culture's Consequences: Comparing Values, Behaviors, Institutions, and Organizations Across Nations, Sage, Thousand Oaks, CA.

Janis, I.L. (1972), Victims of Groupthink: A Psychological Study of Foreign-policy Decisions and Fiascoes, Houghton Mifflin, Boston, MA.

Jaworski, B.J. and MacInnis, D.H. (1989), "Marketing jobs and management control: toward a framework", Lournal of Marketing Research, Vol. 4, November, pp. 406-19.

Jehn, K.A. (1994), "Enhancing effectiveness: an investigation of advantages and disadvantages of value-based intergroup conflict", International Iournal of Conflict Management, Vol. 5 No. 3, pp. 223-38.

Jehn, K.A. (1997), "A qualitative analysis of conflict types and dimensions in organizational groups”, Administrative Science Quarterlv, Vol. 42, September, pp. 530-57.

Kale, P., Dyer, J. and Singh, H. (2002), “Alliance capability, stock market response, and long-term aliiance success: the role of the alliance function", Strategic Management Iournal, Vol. 23 No. 8, pp. 747-67. 
Kale, P., Singh, H. and Perlmutter, H. (2000), "Learning and protection of proprietary assets in strategic alliances: building relational capital”, Strategic Management Iournal, Vol. 21 No. 3, pp. 217-37.

Kandampully, J. (2002), "Innovation as the core competency of a service organisation: the role of technology, knowledge and networks", Eurobean Journal of Innovation Management, Vol. 5, pp. 18-26.

Knemeyer, A.M., Corsi, T.M. and Murphy, P.R. (2003), "Logistics outsourcing relationships: customer perspectives”, Lournal of Business Logistics, Vol. 24 No. 1, pp. 77-109.

Kumar, N., Stern, L.W. and Anderson, J.C. (1993), "Conducting interorganizational research using key informants", Academv of Management Journal, Vol. 36 No. 6, pp. 1633-51.

Lambert, D.M., Emmelhainz, M.A. and Gardner, J.T. (1996), “So you think you want a partner?”, Marketing Management, Vol. 5 No. 2, pp. 24-41.

Lambert, D.M., Emmelhainz, M.A. and Gardner, J.T. (1999), "Building successful logistics partnerships", Journal of Business Logistics, Vol. 20 No. 1, pp. 165-81.

Larson, P.D. and Poist, R.F. (2004), "Improving response rates to mail surveys: a research note", Transportation Iournal, Vol. 43 No. 4, pp. 67-74.

Lemoine, W. and Dagnæs, L. (2003), "Globalisation strategies and business organisation of a network of logistics service providers", International Journal of Phvsical Distribution \& Logistics Management, Vol. 33 No. 3, pp. 209-28.

Li, Y., Xie, E., Teo, H.-H. and Peng, M.W. (2010), "Formal control and social control in domestic and international buyer-supplier relationships", Iournal of Operations Management, Vol. 28 No. 4, pp. 333-44.

Ludvigsen, J. (2000), The International Networking between European Logistical Operators, Economic Research Institute, Stockholm.

Menon, A., Bharadwaj, S.G. and Howell, R. (1996), "The quality and effectiveness of marketing strategy: effects of functional and dysfunctional conflict in intraorganizational relationships", Iournal of the Academv of Marketing Science, Vol. 24 No. 4, pp. 299-313.

Midoro, R. and Pitto, A. (2000), "A critical evaluation of strategic alliances in liner shipping", Maritime Policy \& Management, Vol. 27 No. 1, pp. 31-40.

Moore, K.R. (1998), "Trust and relationship commitment in logistics alliances: a buyer perspective", The Journal of Supply Chain Management, Vol. 34 No. 1, pp. 24-37.

Murray, J.Y. and Kotabe, M. (2005), "Performance implications of strategic fit between alliance attributes and alliance forms", Journal of Business Research, Vol. 58 No. 11, pp. 1525-33.

Nielson, B.B. and Nielsen, S. (2009), "Learning and innovation in international strategic alliances: an empirical test of the role of trust and tacitness", Lournal of Management Studies, Vol. 46 No. 6, pp. 1031-56.

Nijkamp, P. (1995), "From missing networks to interoperable networks: the need for European cooperation in the railway sector", Transport Policv, Vol. 2 No. 3, pp. 159-67.

Nunnally, J.C. (1978), Psychometric Theory, McGraw-Hill, New York, NY.

Ohnell, S. and Woxenius, J. (2003), “An industry analysis of express freight from a European railway perspective", International Iournal of Phvsical Distribution \& Logistics Management, Vol. 33 No. 8, pp. 735-51.

Ouchi, W. (1979), "A conceptual framework for the design of organizational control mechanisms", Management Science, Vol. 25 No. 9, pp. 833-48.

Oum, T.H., Park, J.-H. and Zhang, A. (2000), Globalization and Strategic Alliances: The Case of the Airline Industry, Pergamon Press, London.

\section{Conflict and its} governance

397 
IJPDLM

41,4

398
Oum, T.H., Park, J.-H., Kim, K. and Yu, C. (2004), "The effect of horizontal alliances on firm productivity and profitability: evidence from the global airline industry", Iournal of Business Research, Vol. 57 No. 8, pp. 844-53.

Pascale, R. (1990), “The renewal factor: constructive contention”, Planning Review, July-August, pp. 47-8.

Poppo, L. and Zenger, T. (2002), "Do formal contracts and relational governance function as substitutes or complements?", Strategic Management Journal, Vol. 23 No. 8, pp. 707-25.

Rindfleisch, A. (2000), "Organizational trust and interfirm cooperation: an examination of horizontal versus vertical alliances”, Marketing Letters, Vol. 11 No. 1, pp. 81-95.

Saxton, T. (1997), "The effects of partner and relationship characteristics on alliance outcomes", Academv of Management Journal, Vol. 40 No. 2, pp. 443-61.

Schmoltzi, C. and Wallenburg, C.M. (2009), "Architecture of horizontal cooperations between logistics service providers: an empirical exploration of cooperation types, cooperation motives and governance patterns", paper presented at the 21st Annual NOFOMA Conference, Jönköping, 11-12 June.

Schweiger, D.M., Sandberg, W.R. and Rechner, P.L. (1989), "Experiential effects of dialectical inquiry, devil's advocacy, and consensus approaches to strategic decision making", Academy of Management Journal, Vol. 32 No. 4, pp. 745-72.

Slack, B., Comtois, C. and Mccalla, R. (2002), "Strategic alliances in the container shipping industry: a global perspective”, Maritime Policy \& Management, Vol. 29 No. 1, pp. 65-76.

Stank, T.P., Goldsby, T.J., Vickery, S.K. and Savitskie, K. (2003), "Logistics service performance: estimating its influence on market share", Lournal of Business Logistics, Vol. 24 No. 1, pp. 27-46.

Stefansson, G. (2006), "Collaborative logistics management and the role of third-party service providers", International Iournal of Phvsical Distribution \& Logistics Management, Vol. 36 No. 2, pp. 76-92.

Tate, K. (1996), "The elements of a successful partnership", International Journal of Physical Distribution \& Logistics Management, Vol. 26 No. 3, pp. 7-13.

Tidström, A. (2009), "Causes of conflict in intercompetitor cooperation", Lournal of Business \& Industrial Marketing Marketing, Vol. 24 No. 7, pp. 506-18.

Verstrepen, S., Cools, M., Cruijssen, F. and Dullaert, W. (2009), "A dynamic framework for managing horizontal cooperation in logistics", International Journal of Logistics Systems and Management, Vol. 5 Nos 3/4, pp. 228-48.

Wagner, S.M. (2008), "Innovation management in the German transportation industry", Lournal of Business Logistics, Vol. 29 No. 2, pp. 215-31.

Wallenburg, C.M. (2009), "Innovation in logistics outsourcing relationships: proactive improvement of logistics service providers as a driver of customer loyalty", Journal of Subplv Chain Management, Vol. 45 No. 2, pp. 75-93.

Zaltman, G., Duncan, R. and Holbek, J. (1973), Innovations and Organizations, Wiley, New York, NY.

\section{Further reading}

Zaheer, A., McEvily, B. and Perrone, V. (1998), "Does trust matter? Exploring the effects of interorganizational and interpersonal trust on performance", Organization Science, Vol. 9 No. 2, pp. 141-59. 


\section{Appendix}

Measurement scales

Measurement scales

Cooperation performance ${ }^{\mathrm{a}}$ (Kale et al., 2002; Saxton, 1997)

Cronbach's alpha $=0.92$

The cooperation has achieved its primary objectives

The cooperation is very productive

Owing to the cooperation, we could greatly enhance our company's competitive position

All in all, we are very satisfied with the results of the cooperation

Cooperation-based innovation ${ }^{\mathrm{a}}$ (Nielson and Nielsen, 2009)

Cronbach's alpha $=0.86$

Owing to the cooperation we...

....were able to modify products and processes

... gained know-how/technologies that are useful also for new projects

... were able to implement unexpected product/process enhancements and innovations

Conflict extent ${ }^{\mathrm{a}}$ (Amason, 1996)

Cronbach's alpha $=0.92$

Our cooperation partners and we...

...often have disagreements on decisions

... have many differences on evaluating and prioritizing tasks

... often have different opinions

Conflict functionality ${ }^{\mathrm{a}}$

Cronbach's alpha $=0.89$

Conflicts...

... are lead very personal and emotional. - . . always stay task oriented

... hamper our cooperation. - . . .enhance our cooperation

... are very destructive. - . . . are very productive

Formalization ${ }^{\text {a }}$ (Murray and Kotabe, 2005)

Cronbach's alpha $=0.88$

In our cooperation we have...

...written documents (e.g. handbooks) that spell out detailed tasks, activities and schedules for the cooperation

...detailed standard operating procedures (e.g. rules, policies, forms, etc.) for the processes of the cooperation

Relational capital ${ }^{\mathrm{a}}$ (Kale et al., 2000)

Cronbach's alpha $=0.89$

The cooperation is characterized by...

...close personal interaction

...mutual respect between the partners

...mutual trust

...personal friendship

...high reciprocity
$4.82 \quad 1.75$

Mean SD

$5.07 \quad 1.41$

$5.22 \quad 1.54$

$5.15 \quad 1.45$

$4.33 \quad 1.79$

$4.46 \quad 1.77$

$3.91 \quad 1.80$

$2.87 \quad 1.50$

$2.93 \quad 1.51$

$3.04 \quad 1.53$

$4.38 \quad 1.74$

$4.32 \quad 1.72$
$4.96 \quad 1.54$

$4.57 \quad 2.30$

Note: ${ }^{\text {aC }}$ orresponding items are measured on a seven-point Likert-scale where 1 - strongly disagree and 7 - strongly agree

Conflict and its governance

399

1

(1)




\section{IJPDLM}

41,4

400

\section{About the authors}

Carl Marcus Wallenburg (Kühne-Foundation Chair of Logistics and Services Management $\mathrm{PhD}$, WHU - Otto Beisheim School of Management) is a Professor of Logistics and the Kuehne-Foundation Chair of International Logistics Networks at the Technische Universität Berlin, Germany. His research focuses on third-party logistics, relationship management, and international SCM. He frequently speaks at conferences and company meetings and is the author of five books. His work has been accepted to various journals including European Journal of Marketing, International Journal of Logistics Management, International Journal of Physical Distribution \& Logistics Management, Journal of Business Logistics, Journal of Supply Chain Management, and Transportation Journal. Carl Marcus Wallenburg is the corresponding author and can be contacted at: wallenburg@whu.edu Jan Simon Raue (Dipl.-Wi.-Ing., Universität Karlsruhe) is a PhD Candidate and Research Associate in Logistics at the Kuehne-Foundation Chair of International Logistics Networks at Technische Universität Berlin, Germany. His research interests focus on strategic alliances and horizontal cooperations of logistics service providers.

To purchase reprints of this article please e-mail: reprints@emeraldinsight.com Or visit our web site for further details: www.emeraldinsight.com/reprints 


\section{This article has been cited by:}

1. GaoHuijie, Huijie Gao, YangJianhua, Jianhua Yang, YinHuanwu, Huanwu Yin, MaZhiChao, ZhiChao Ma. 2017. The impact of partner similarity on alliance management capability, stability and performance. International Journal of Physical Distribution \& Logistics Management 47:9, 906-926. [Abstract] [Full Text] [PDF]

2. Felix Reimann, Tobias Kosmol, Lutz Kaufmann. 2017. Responses to Supplier-Induced Disruptions: A Fuzzy-Set Analysis. Journal of Supply Chain Management 53:4, 37-66. [Crossref]

3. Elaine Aparecida Regiani de Campos, Luis Mauricio Resende, Joseane Pontes. 2017. Barriers, external aspects and trust factors in horizontal networks of companies: a theoretical proposal for the construction of a model for evaluation of trust. Journal of Intelligent Manufacturing 47. . [Crossref]

4. Carl Marcus Wallenburg, Thorsten Schäffler. 2016. Performance measurement in horizontal LSP cooperation as a field of conflict: the preventive role of collaborative processes. Logistics Research 9:1. . [Crossref]

5. I-Shuo Chen, Fang-Tai Tseng. 2016. The relevance of communication media in conflict contexts and their effectiveness: A negotiation experiment. Computers in Human Bebavior 59, 134-141. [Crossref]

6. Lisa Brekalo, Sascha Albers. 2016. Effective logistics alliance design and management. International Journal of Physical Distribution \& Logistics Management 46:2, 212-240. [Abstract] [Full Text] [PDF]

7. Vasco Sanchez Rodrigues, Irina Harris, Robert Mason. 2015. Horizontal logistics collaboration for enhanced supply chain performance: an international retail perspective. Supply Chain Management: An International Journal 20:6, 631-647. [Abstract] [Full Text] [PDF]

8. Jan Simon Raue, Andreas Wieland. 2015. The interplay of different types of governance in horizontal cooperations. The International Journal of Logistics Management 26:2, 401-423. [Abstract] [Full Text] [PDF]

9. Jason Monios, Rickard Bergqvist. 2015. Using a "virtual joint venture" to facilitate the adoption of intermodal transport. Supply Chain Management: An International Journal 20:5, 534-548. [Abstract] [Full Text] [PDF]

10. Yingli Wang, Vasco Sanchez Rodrigues, Leighton Evans. 2015. The use of ICT in road freight transport for CO2 reduction - an exploratory study of UK's grocery retail industry. The International Journal of Logistics Management 26:1, 2-29. [Abstract] [Full Text] [PDF]

11. Elena Pérez-Bernabeu, Angel A. Juan, Javier Faulin, Barry B. Barrios. 2015. Horizontal cooperation in road transportation: a case illustrating savings in distances and greenhouse gas emissions. International Transactions in Operational Research 22:3, 585-606. [Crossref]

12. Lamis E. Amer, Amr B. Eltawil. Analysis of quantitative models of horizontal collaboration in supply chain network design: Towards \&\#x201C;green collaborative\&\#x201D; strategies 1-10. [Crossref]

13. Francesco Pomponi, Luciano Fratocchi, Silvia Rossi Tafuri. 2015. Trust development and horizontal collaboration in logistics: a theory based evolutionary framework. Supply Chain Management: An International Journal 20:1, 83-97. [Abstract] [Full Text] [PDF]

14. Carl Marcus Wallenburg, Thorsten Schäffler. 2014. The Interplay of Relational Governance and Formal Control in Horizontal Alliances: A Social Contract Perspective. Journal of Supply Chain Management 50:2, 41-58. [Crossref] 
15. Rudolf Leuschner, Craig R. Carter, Thomas J. Goldsby, Zachary S. Rogers. 2014. Third-Party Logistics: A Meta-Analytic Review and Investigation of its Impact on Performance. Journal of Supply Chain Management 50:1, 21-43. [Crossref]

16. Lisa Brekalo, Sascha Albers, Werner Delfmann. 2013. Logistics alliance management capabilities: where are they?. International Journal of Physical Distribution \& Logistics Management 43:7, 529-543. [Abstract] [Full Text] [PDF]

17. Qin Zhu, Richard Y.K. Fung. Design and analysis of optimal incentive contracts between fourth-party and third-party logistics providers 84-89. [Crossref]

18. Kevin Burgess, Prakash J. Singh. 2012. Using the social system of a supply chain to improve a focal organization's operating performance. Operations Management Research 5:1-2, 57-68. [Crossref] 